\title{
Assessment of Good Agricultural Practices on Cocoa and Coffee Farms in Northern Haiti
}

\author{
Abraham Navarro1, Elliott Currie ${ }^{2}$, Donald G. Mercer $^{3 *}$ \\ ${ }^{1}$ Daiya Foods Inc., Vancouver, BC, Canada \\ ${ }^{2}$ Department of Management, Gordon S. Lang School of Business and Economics, University of Guelph, \\ Guelph, ON, Canada \\ ${ }^{3}$ Department of Food Science, Ontario Agricultural College, University of Guelph, Guelph, ON, Canada \\ Email: ab.navarro@gmail.com, ecurrie@uoguelph.ca, ^dmercer@uoguelph.ca
}

How to cite this paper: Navarro, A., Currie, E. and Mercer, D.G. (2020) Assessment of Good Agricultural Practices on Cocoa and Coffee Farms in Northern Haiti. Agricultural Sciences, 11, 803-836. https://doi.org/10.4236/as.2020.119052

Received: March 5, 2020

Accepted: September 24, 2020

Published: September 27, 2020

Copyright $\odot 2020$ by author(s) and Scientific Research Publishing Inc. This work is licensed under the Creative Commons Attribution International License (CC BY 4.0).

http://creativecommons.org/licenses/by/4.0/

\begin{abstract}
Haiti is the poorest country in the Western Hemisphere and presents a unique scenario for the food and agriculture industry, because there is no food safety legislation. The application of Good Agricultural Practices (GAPs) leads to improvements of quality, safety and sustainability of agricultural products. The purpose of the study was to assess the status of Good Agricultural Practices (GAPs) in cocoa and coffee farms in Northern Haiti. A general survey captured information about the farmer and the farm, and an audit checklist was used to assess compliance to GAPs. A total of 11 farms $(\mathrm{n}=11)$ were audited, of which 7 were cocoa farms (64\%) and 4 were coffee farms (34\%) in the regions of Dondon, Limonade and Milot. Average overall audit scores for coffee farms (73\%) were higher than for cocoa farms (55\%). Farms affiliated with a cooperative scored higher (78\%) than those that were not part of a cooperative (55\%). The sections of the survey on "Practices related to premises and production site", and the "use of agricultural inputs and chemicals" received the lowest scores but were confined to the cocoa farms. "Record keeping" plus "distribution, transportation, and traceability" were cause for concern with both the cocoa and coffee farms. Critical non-conformances included the access of livestock animals and domestic pets to processing and storage areas, the lack of control in the application of agricultural chemicals, a lack of safeguards on equipment and elevated surfaces, and washing of fresh cocoa beans to remove the mucilage with water that had not been treated or tested for potability. The root cause of the non-conformances, regardless of the commodity, was either related to poor physical and organizational infrastructures, or to a lack of technical training.
\end{abstract}




\section{Keywords}

Haiti, Sustainability, Good Agricultural Practices, Cocoa, Coffee, Food Safety, Quality

\section{Introduction}

\subsection{Haiti}

Haiti is the poorest country in the western hemisphere. It ranked 163 out of 188 countries in the Human Development Index (HDI) for 2016 based on life expectancy, health, knowledge, education and living standards [1]. Many people are living below the poverty line with less than \$2 US per day [2]; half of the population is undernourished [3]; $40 \%$ of people aged 15 or older are illiterate [1]; less than $40 \%$ of the population has access to electricity [4] and $70 \%$ do not have access to potable water sources [5]. These factors have hindered Haiti's development and have forced it to rely on international assistance [6] [7], with over $20 \%$ of the government's budget coming from external assistance alone [6]. According to the Observatory of Economic Complexity (OEC), Haiti exported $\$ 2.08 \mathrm{~B}$ (US\$) worth of goods in 2016 [8]. Knitted and other apparel accounted for half of this amount, leaving $\$ 1.04 \mathrm{~B}$ for the remaining sectors of the economy. Cocoa bean accounted for $\$ 13.3 \mathrm{M}(1.3 \%)$ of the non-apparel exports, while green coffee beans contributed only $\$ 649 \mathrm{~K}(0.062 \%)$ to these exports. Other significant agricultural-based exports included essential oils ( $\$ 29.6 \mathrm{M}, 2.8 \%)$, tropical fruits ( $\$ 9.42 \mathrm{M}, 0.91 \%)$, and alcoholic beverages ( $\$ 4.35 \mathrm{M}, 0.44 \%)$ [8].

Haiti has no food safety legislation [9] and its government systems are so complex that addressing food safety is challenging [10]. Currently, the data available on food safety issues, knowledge, attitudes and regulation in Haiti are limited. Few studies have been published and they portray a high-risk panorama: high prevalence of heavy metals in water and high level of aflatoxins in peanut products [11]; high-risk transmission factors of food-borne illnesses due to a lack of soap, poor personal hygiene practices and food from street vendors [12]; limited access to potable water, lack of appropriate waste disposal facilities and insufficient knowledge and awareness of food safety practices among street vendors [9]. Overall, it is reasonable to say that in Haiti the information on food safety issues is limited, surveillance is non-existent, the government's capacity to respond to outbreaks is not optimal [11], personal hygiene practices need to improve [12] and there is an urgent need to organize formal training on food hygiene and safety practices [9]. It is with a focus on the potential of migrating GAPs from cash crops like coffee and cocoa to other crops that the research was initiated.

\subsection{Good Agricultural Practices}

Good Agricultural Practices (GAPs) are technical recommendations and guide- 
lines "that address environmental, economic and social sustainability for on-farm processes, and result in safe and quality food and non-food agricultural products" [13]. Its framework contains guiding principles concerning the environment (e.g., soil, water, energy and waste management, wildlife and landscape), farming activities (e.g., animal production, crop production and protection, harvest, processing and storage) and welfare (e.g., animal welfare and health, human welfare, health and safety) [14]. Private standards have been developed by multiple stakeholders to determine the minimum food safety standards, but they are not mandatory. Among the most recognized standards by retailers and manufacturers are the British Retail Consortium (BRC) global standards, Safe Quality Food (SQF), USGAP, ISO19011:2018, GlobalGAP and Canada GAP, all under the umbrella of the Global Food Safety Initiative (GFSI) through its benchmarking process [14]. Though there are benefits in following and monitoring GAPs, the challenges in implementing them must be considered, especially for small farmers of developing countries. The impact of implementing food safety and quality standards on farms is dependent on farm size, agricultural sector, and country [15]. Meeting international standards gives access to international markets, and it also helps improve hygiene and health of workers, modernize production processes, increase yields and quality of product [16] and enhance financial gains in the long run [15]. However, in developing countries food security is a priority and the prices of food need to be kept affordable [17]. The probability that small-scale farmers pursue certification on food safety and quality standards is very low due to the high costs and complex technical knowledge associated with stringent standards [16] [17]. However, not doing so might exclude them from international markets because the standards are gaining more and more importance in trade [16]. Some of the challenges associated with certification are: the lack of funds for initial investment, certification fees and laboratory analyses [16]; the use of traceability and record keeping systems [15]; and the development of technical skills to manage, supervise and maintain the standards [17]. In order to overcome these challenges, it has been suggested that policies are needed allowing small-scale farmers to have access to financial and technical assistance in developing countries [15]. Another issue is the low level of literacy among the Haitian population that may build an additional barrier to comprehending and implementing any record keeping and management system.

\subsection{Cocoa and Coffee}

Cocoa and coffee beans are high-value commodities, driven by the chocolate confectionery industry, baking industry and ice cream industry for cocoa [18], and by the hot beverage industry for coffee [19]. It is expected that the demand for these products will continue to have a stable growth worldwide [20] [21]. In spite of the growing demand over the past century, Haiti has dropped from the third largest exporter of coffee in 1949 to one of the smallest producers and ex- 
porters. (39)

The Canadian Food Inspection Agency (CFIA) [22] has identified the potential hazards in cocoa beans and related products. There are chemical hazards (e.g., pesticide residues, undeclared allergens and contamination by non-food chemicals) and physical hazards (e.g., extraneous material) that can be addressed with the implementation of GAPs.

Cocoa and cocoa products also have Salmonella spp. as a biological hazard [22] and ochratoxin A (OTA) as a chemical hazard [23]. Salmonella spp. present in livestock and domestic pets, are transmitted to food through the fecal-oral route or contaminated water [24]. The source of some outbreaks has been traced back to cocoa beans [25]. Low water activity (aw) and high fat content of cocoa beans make the bacteria viable for prolonged periods. Contamination can occur during pre-processing activities (e.g., harvest, fermentation, drying, storage) on the farm due to poor hygienic conditions. It is best to control this potential contamination with good agricultural practices (GAPs) at the farm level [25], and through thermal processes such as roasting and conching in the food industry [26]. OTA is produced by Aspergillus carbonarius and Aspergillus niger, and is one of the most common mycotoxins found in cocoa beans [27]. Cocoa beans can become contaminated because of damaged pods, poor fermentation, slow drying and poor storage [28], but it is in the latter two stages that OTA is produced at higher levels due to low water activity (aw) and lower microbial competition [27]. It has been reported that the processing steps that remove the most OTA in cocoa beans are shelling and alkalinisation [29]. Even though chocolate products are minor source of OTA, consideration must be given as low levels in large quantities can be consumed by children [28].

Contamination of coffee beans with various microorganisms, particularly filamentous fungi, and the subsequent potential production of ochratoxin $\mathrm{A}$ is also food safety concern. It can occur at the farm level and throughout the production chain [30]. Microbial loads are frequently reduced during the roasting process. However, precautionary measures are essential at each stage of the production chain to minimize the risk to consumers.

The purpose of the study was to assess the status of Good Agricultural Practices (GAPs) in cocoa and coffee farms in Northern Haiti, and to identify the most common practices that would compromise the food safety and quality of Haitian cocoa and coffee beans.

\section{Materials and Methods}

\subsection{Sample Selection}

The study was carried out in Northern Haiti (Figure 1) with the assistance of the Haiti Food Hub (HFH). HFH is a local enterprise run by Haitians whose mission is to promote a social agri-business model that is financially self-sustainable by helping small-scale farmers supply quality products, while improving social and environmental conditions. The project was reviewed by the University of Guelph 


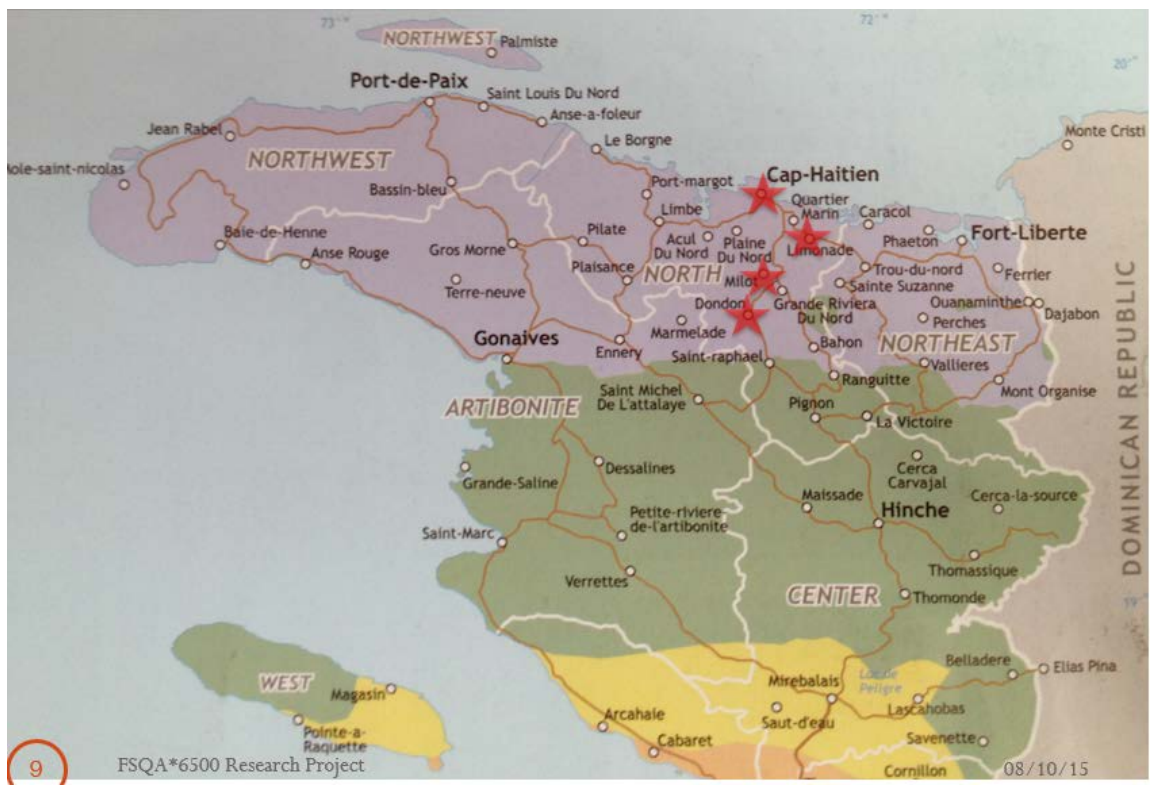

Figure 1. Location of surveys of producers in Northern Haiti.

Research Ethics Boards (REB) and granted approval (REB no. 15AP010). Selection criteria mandated that participants must do so on a strictly voluntary basis, be of legal age, and have been actively involved with the Haiti Food Hub prior to this study. There were also language stipulations (Creole, English, or Spanish), due to the availability of interpreters. As such, French-speaking farmers were excluded from the survey pool. A letter was sent to the HFH agronomist inviting interested parties from the 70 cocoa farmers and 70 coffee producers affiliated with the HFH to participate in this study. Based upon these criteria, a sample of 7 cocoa farms and 4 coffee farms was obtained after recruiting participants. Farmers who expressed interest were given a more detailed explanation of their involvement in the project. After giving their oral consent, a consent form in Creole was distributed. While this was a somewhat low number of participants, it was considered appropriate in providing an initial baseline in identifying current practices employed on typical small-scale farming operations for cocoa and coffee. There were also time and budgetary constraints that made it impractical to survey a larger sample size. It was considered that the results would provide directionality for future studies and preferably actions to improve the agricultural practices and economic outlook for Haitian agricultural producers.

\subsection{General Survey}

A general survey was adapted from Ganpat et al. [31] to capture information about the farmer (i.e., gender, age, farming experience, level of education, agricultural training, number of household members and income sources) and about the farm (i.e., region, nearest town or city, farm size, production yields, cooperative affiliation, land status, export status, certification status, other crops grown and presence of livestock animals). The questions were multiple-choice, or 
open-ended whenever specific information was required. A code was assigned to each participant based on the crop of interest, followed by a two-digit number to indicate the number of the farm belonging to that category. "CC" was assigned to cocoa producers and "CF" to coffee producers. The codes $\mathrm{CC} 01$ to $\mathrm{CC} 07$ were assigned to the seven participating cocoa farms, and CF01 to CF04 designated the four coffee farms involved. Appendix A shows the form that was used to collect the data described above.

\subsection{Audit Checklist}

An audit checklist was developed considering FAO guiding principles of good agricultural practices [13]. The audit checklist was developed integrating information from Ganpat, et al. [31] GAP questionnaire, Canada GAP [32] Food Safety Manual for Fresh Fruits and Vegetables (version 6.2), and FAO [33] Good Agricultural Practices for Family Agriculture guidelines. The risk assessment of production sites and water sources was done following Form K of Canada GAP [34] Food Safety Manual Appendices. The checklist was divided in 9 sections:

1) Production Site and Premises

2) Sanitation and Waste Management

3) Use of Agricultural Inputs and Chemicals

4) Water Quality

5) Harvest and Post-Harvest Operations

6) Equipment and Tools

7) Distribution, Transportation and Traceability

8) Human Welfare, Health and Safety

9) Record Keeping

Each section contained several items that described the specific practices to be assessed and a severity value associated with it, depending on the potential impact on food safety. The number of items per section varied, but the weight of total points was evenly distributed throughout the sections, ranging from $9 \%$ to 13\% (Figure 2). The audit checklist had a total of 57 items.

Each practice was assessed on-site through observation and/or objective evidence provided by the farmer (e.g., records, labels) and, in some cases, photographs were taken to document the objective evidence.

Items were classified and assigned a numeric value using the criteria outlined in Table 1.

Each item was pre-assigned a numeric value based on the severity of not following the practices as described: 1-Low (minor); 2-Medium (serious); 3-High (hazardous). This was done in order to give more points to high severity practices that were compliant. The rating of each item was obtained by multiplying the severity value times the numeric score assigned for the status of compliance (value $=3$ ) or non-conformance (value $=2,1$ or 0 ) of the practice. If the specific item was not applicable to the farm, "N/A" was marked in the rating column, a rationale was provided in the "Comments" column and it was not considered in 


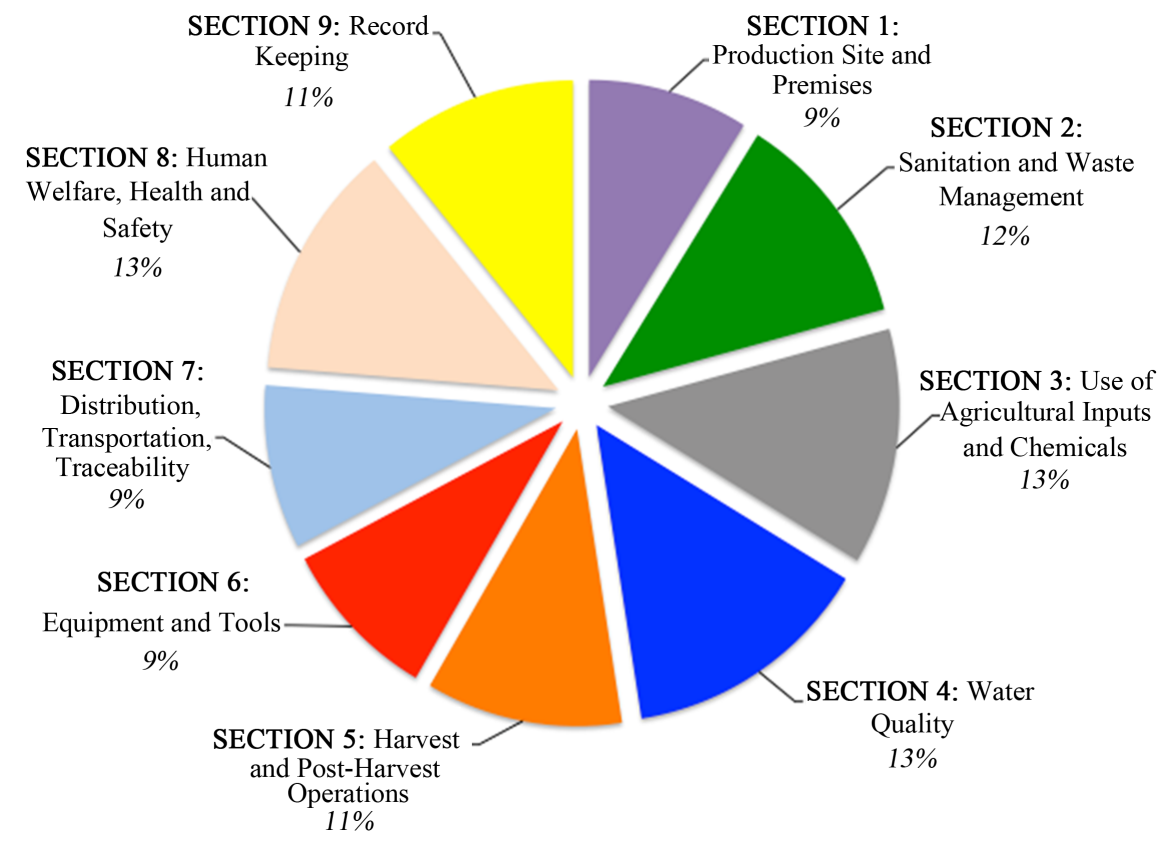

Figure 2. Distribution of points per section in the audit checklist.

Table 1. Criteria and scores for item classifications.

\begin{tabular}{|c|c|c|}
\hline Classification & Criteria & Numerical Score \\
\hline Compliant & $\begin{array}{l}\text { All practices were followed as described and } \\
\text { objective evidence was observed. }\end{array}$ & 3 \\
\hline $\begin{array}{c}\text { Minor } \\
\text { Non-Conformance }\end{array}$ & $\begin{array}{l}\text { All practices were followed as described but no } \\
\text { objective evidence was observed; some of the } \\
\text { practices were not followed as described. }\end{array}$ & 2 \\
\hline $\begin{array}{c}\text { Major } \\
\text { Non-Conformance }\end{array}$ & $\begin{array}{l}\text { There was evidence that most practices } \\
\text { were not followed as described. }\end{array}$ & 1 \\
\hline $\begin{array}{l}\text { Critical } \\
\text { Non-Conformance }\end{array}$ & $\begin{array}{l}\text { Controls were not in place and the practices } \\
\text { followed posed a public health risk if } \\
\text { no corrective actions were implemented. }\end{array}$ & 0 \\
\hline
\end{tabular}

final score. To calculate scores, total points and maximum points were used $[$ Score $(\%)=($ Points obtained/Maximum points $) \times 100]$. Maximum points were calculated by assuming that all practices were compliant, excluding those that were not applicable (N/A). Each section score (\%) was calculated dividing the points obtained per section by the maximum points per section. The overall audit score of the farm (\%) was calculated dividing the sum of points obtained in all sections by the sum of maximum points of all sections. Appendix 1 contains the complete audit checklist used to assess the farms.

\section{Results}

\subsection{Farmer Information}

Information gathered in the survey that is specific to the farmers is summarized in Table 2. A total of 11 farms $(n=11)$ were audited, out of which 7 were cocoa 
Table 2. Results of survey information about the farmers.

\begin{tabular}{|c|c|c|c|}
\hline & \multicolumn{3}{|c|}{ Crop of Interest } \\
\hline & Cocoa & Coffee & Total \\
\hline Number of Farms & $7(64 \%)$ & $4(36 \%)$ & $11(100 \%)$ \\
\hline \multicolumn{4}{|l|}{ Gender: } \\
\hline Female & $0(0 \%)$ & $1(25 \%)$ & $1(9 \%)$ \\
\hline Male & $7(100 \%)$ & $3(75 \%)$ & $10(91 \%)$ \\
\hline \multicolumn{4}{|l|}{ Age: } \\
\hline 19 to 30 years & $1(14 \%)$ & $0(0 \%)$ & $1(9 \%)$ \\
\hline 31 to 45 years & $1(14 \%)$ & $2(50 \%)$ & $3(27 \%)$ \\
\hline$>45$ years & $5(71 \%)$ & $2(50 \%)$ & $7(64 \%)$ \\
\hline \multicolumn{4}{|l|}{ Farming Experience: } \\
\hline $5-10$ years & $1(14 \%)$ & $0(0 \%)$ & $1(9 \%)$ \\
\hline $11-20$ years & $1(14 \%)$ & $0(0 \%)$ & $1(9 \%)$ \\
\hline 21 - 30 years & $0(0 \%)$ & $2(50 \%)$ & $2(18 \%)$ \\
\hline$>30$ years & $5(72 \%)$ & $2(50 \%)$ & $7(64 \%)$ \\
\hline \multicolumn{4}{|l|}{ Education Level: } \\
\hline None & $1(14 \%)$ & $0(0 \%)$ & $1(9 \%)$ \\
\hline Elementary & $3(43 \%)$ & $1(25 \%)$ & $4(36 \%)$ \\
\hline Middle School & $3(43 \%)$ & $0(0 \%)$ & $3(27 \%)$ \\
\hline High School & $0(0 \%)$ & $2(50 \%)$ & $2(27 \%)$ \\
\hline Other & $0(0 \%)$ & $1(25 \%)$ & $1(9 \%)$ \\
\hline \multicolumn{4}{|l|}{ Agricultural Training: } \\
\hline "No" & $7(100 \%)$ & $1(25 \%)$ & $8(73 \%)$ \\
\hline "Yes" & $0(0 \%)$ & $3(75 \%)$ & $3(27 \%)$ \\
\hline \multicolumn{4}{|l|}{ Household Members: } \\
\hline 3 - 5 members & $2(29 \%)$ & $0(0 \%)$ & $2(18 \%)$ \\
\hline $6-8$ members & $3(43 \%)$ & $2(50 \%)$ & $5(45 \%)$ \\
\hline 9 or more & $2(29 \%)$ & $2(50 \%)$ & $4(36 \%)$ \\
\hline \multicolumn{4}{|c|}{ Income Just from Farming: } \\
\hline "No" & $6(86 \%)$ & $4(100 \%)$ & $10(91 \%)$ \\
\hline "Yes" & $1(14 \%)$ & $0(0 \%)$ & $1(9 \%)$ \\
\hline
\end{tabular}

farms $(64 \%)$ and 4 were coffee farms (36\%). The majority of participants were male (91\%) with only one female farmer in the coffee sector. It was found that $64 \%$ of the farmers were over the age of 45 years old, and only one of them was 30 years old or younger. Since most of the participants have lived their entire lives in a farming environment, the survey showed that $64 \%$ of them are very experienced, having more than 30 years of farming experience. In spite of the 
many years of experience, no cocoa farmer had received formal agricultural training compared to $75 \%$ of coffee farmers who had had some sort of training through a cooperative or an international program. In $82 \%$ of the cases, households had six or more family members living in the same house, and $91 \%$ had another source of income besides farming-related activities.

\subsection{Farm Information}

Table 3 provides general information about the farm. Three regions in Northern Haiti were surveyed: Dondon, Limonade, and Milot. The region of Dondon was

Table 3. Results of survey information about the farms.

\begin{tabular}{|c|c|c|c|}
\hline & \multicolumn{3}{|c|}{ Crop of Interest } \\
\hline & Cocoa & Coffee & Total \\
\hline Number of Farms & $7(64 \%)$ & $4(36 \%)$ & $11(100 \%)$ \\
\hline \multicolumn{4}{|l|}{ Nearest City/Town: } \\
\hline Dondon & $0(0 \%)$ & $3(75 \%)$ & $3(27 \%)$ \\
\hline Limonade & $4(57 \%)$ & $1(25 \%)$ & $5(45 \%)$ \\
\hline Milot & $3(43 \%)$ & $0(0 \%)$ & $3(27 \%)$ \\
\hline \multicolumn{4}{|l|}{ Farm Size: } \\
\hline$<1$ hectare & $2(29 \%)$ & $3(75 \%)$ & $5(45 \%)$ \\
\hline $1-5$ hectares & $5(71 \%)$ & $1(25 \%)$ & $6(55 \%)$ \\
\hline \multicolumn{4}{|l|}{ Co-op Affiliation: } \\
\hline "No" & $7(100 \%)$ & $1(25 \%)$ & $8(73 \%)$ \\
\hline "Yes" & $0(0 \%)$ & $3(75 \%)$ & $3(27 \%)$ \\
\hline \multicolumn{4}{|l|}{ Land Status: } \\
\hline Owned & $6(86 \%)$ & $4(100 \%)$ & $10(91 \%)$ \\
\hline Rented & $1(14 \%)$ & $0(0 \%)$ & $1(9 \%)$ \\
\hline \multicolumn{4}{|l|}{ Export Status: } \\
\hline Exporter & $0(0 \%)$ & $3(75 \%)$ & $3(27 \%)$ \\
\hline Not an Exporter & $7(100 \%)$ & $1(25 \%)$ & $8(73 \%)$ \\
\hline \multicolumn{4}{|l|}{ Certification: } \\
\hline "No" & $7(100 \%)$ & $2(50 \%)$ & $9(82 \%)$ \\
\hline "Yes" & $0(0 \%)$ & $2(50 \%)$ & $2(18 \%)$ \\
\hline \multicolumn{4}{|l|}{ Other Crops: } \\
\hline Tree Crops & $0(0 \%)$ & $1(25 \%)$ & $1(9 \%)$ \\
\hline Tree + Root Crops & $7(100 \%)$ & $3(75 \%)$ & $10(91 \%)$ \\
\hline \multicolumn{4}{|l|}{ Livestock: } \\
\hline "No" & $3(43 \%)$ & $4(100 \%)$ & $7(64 \%)$ \\
\hline "Yes" & $4(57 \%)$ & $0(0 \%)$ & $4(36 \%)$ \\
\hline
\end{tabular}


characterized by coffee producers, and the region of Milot by cocoa producers. (Figure 1) The farm size of all participants was less than 5 hectares, and $71 \%$ of cocoa farms were between one and five hectares, whereas $75 \%$ of coffee farms were less than 1 hectare. More than $90 \%$ of the farmers owned their land and had tree crops (e.g., mangoes, plantain, sour sop, breadfruit) and root crops (e.g., yams) growing on the farm. None of the cocoa producers that participated in the survey was affiliated with a cooperative nor was exporting their products. However, $75 \%$ of coffee producers (CF02, CF03 \& CF04) were members of a cooperative and $50 \%$ of them (CF02 \& CF03) exported their "Certified Organic" product to the United States (Table 3). Livestock animals were not observed on any of the 4 coffee farms visited. Pigs, chickens, goats, and cattle were seen in 4 of the 7 cocoa farms, regardless of farm size.

\subsection{Audit Scores}

The audit results are reported in Table 4(a) and Table 4(b) for cocoa and coffee farms, respectively.

Similar audit scores are reported for some farms because they were either neighbors that had similar practices (CC01 \& CC02 and CC03 \& CC04), or because they belonged to the same cooperative and followed the same practices (CF02 \& CF03). The average overall score of the seven cocoa farms was 55\%, compared to a higher overall average of $73 \%$ for the four coffee farms.

To aid in comparison of the data, Figure 3 provides a graphical representation of the overall average audit scores from Table 4(a) and Table 4(b) for the cocoa and coffee farms.

As can be seen, the scores for the coffee farms were consistently higher than those for the cocoa farms, with one exception. It was only in Section 6 (Equipment and Tools) that the cocoa farms received a score greater than the coffee farms.

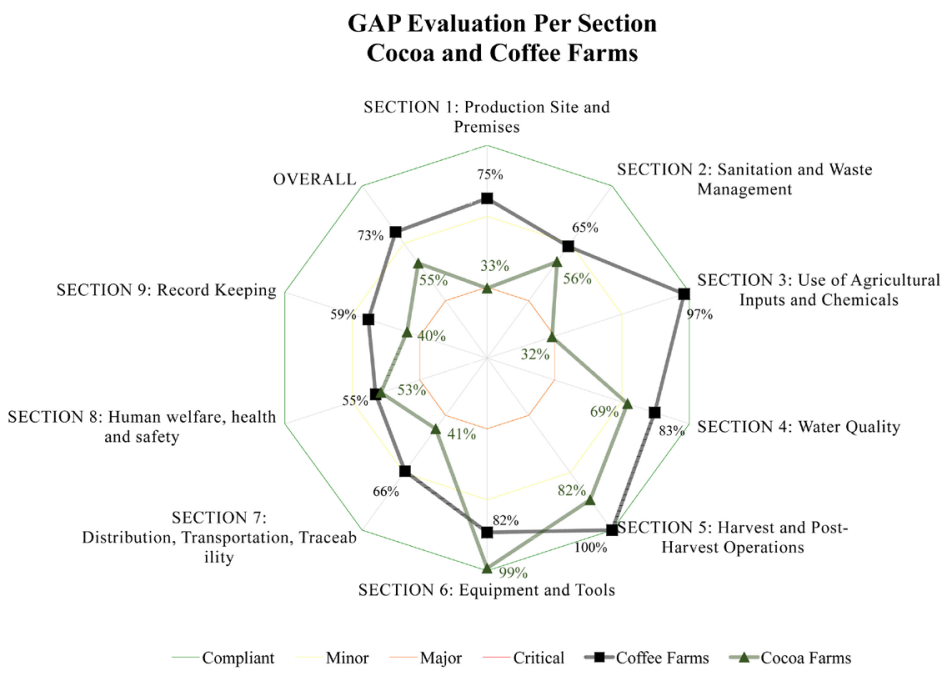

Figure 3. Comparison of audit scores per section and type of farm. 
Table 4. (a) Survey results for cocoa farms; (b) Survey results for coffee farms.

(a)

\begin{tabular}{|c|c|c|c|c|c|c|c|c|c|}
\hline & Section & $\mathrm{CC} 01$ & $\mathrm{CCO} 2$ & $\mathrm{CCO} 3$ & $\mathrm{CCO} 4$ & $\mathrm{CC} 05$ & $\mathrm{CC} 06$ & $\mathrm{CC07}$ & Average \\
\hline 1 & $\begin{array}{l}\text { Production site } \\
\text { and premises }\end{array}$ & $33 \%$ & $33 \%$ & $15 \%$ & $15 \%$ & $19 \%$ & $81 \%$ & $33 \%$ & $33 \%$ \\
\hline 2 & $\begin{array}{c}\text { Sanitation and } \\
\text { waste management }\end{array}$ & $81 \%$ & $81 \%$ & $33 \%$ & $33 \%$ & $33 \%$ & $67 \%$ & $62 \%$ & $56 \%$ \\
\hline 3 & $\begin{array}{l}\text { Use of agricultural } \\
\text { inputs and chemicals }\end{array}$ & $37 \%$ & $37 \%$ & N/A & N/A & N/A & $22 \%$ & N/A & $32 \%$ \\
\hline 4 & Water quality & $67 \%$ & $67 \%$ & $58 \%$ & $58 \%$ & $100 \%$ & $58 \%$ & $78 \%$ & $69 \%$ \\
\hline 5 & $\begin{array}{c}\text { Harvest and } \\
\text { post-harvest operations }\end{array}$ & $70 \%$ & $70 \%$ & $88 \%$ & $88 \%$ & $88 \%$ & $88 \%$ & $88 \%$ & $82 \%$ \\
\hline 6 & Equipment and tools & $100 \%$ & $100 \%$ & $100 \%$ & $100 \%$ & $92 \%$ & $100 \%$ & $100 \%$ & $99 \%$ \\
\hline 7 & $\begin{array}{l}\text { Distribution, traceability, } \\
\text { transportation }\end{array}$ & $41 \%$ & $41 \%$ & $41 \%$ & $41 \%$ & $42 \%$ & $42 \%$ & $42 \%$ & $41 \%$ \\
\hline 8 & $\begin{array}{l}\text { Human welfare, } \\
\text { health, and safety }\end{array}$ & $64 \%$ & $64 \%$ & $41 \%$ & $41 \%$ & $41 \%$ & $53 \%$ & $63 \%$ & $53 \%$ \\
\hline \multirow[t]{2}{*}{9} & Record keeping & $41 \%$ & $41 \%$ & $39 \%$ & $39 \%$ & $33 \%$ & $42 \%$ & $43 \%$ & $40 \%$ \\
\hline & Overall Score & $59 \%$ & $59 \%$ & $48 \%$ & $48 \%$ & $50 \%$ & $61 \%$ & $61 \%$ & $55 \%$ \\
\hline
\end{tabular}

(b)

\begin{tabular}{|c|c|c|c|c|c|c|}
\hline & Section & CF01 & CF02 & CF03 & CF04 & Average \\
\hline 1 & $\begin{array}{l}\text { Production site } \\
\text { and premises }\end{array}$ & $44 \%$ & $89 \%$ & $89 \%$ & $78 \%$ & $75 \%$ \\
\hline 2 & $\begin{array}{c}\text { Sanitation and waste } \\
\text { management }\end{array}$ & $33 \%$ & $75 \%$ & $75 \%$ & $76 \%$ & $65 \%$ \\
\hline 3 & $\begin{array}{l}\text { Use of agricultural } \\
\text { inputs and chemicals }\end{array}$ & N/A & $97 \%$ & $97 \%$ & N/A & $97 \%$ \\
\hline 4 & Water quality & $72 \%$ & $94 \%$ & $94 \%$ & $70 \%$ & $83 \%$ \\
\hline 5 & $\begin{array}{c}\text { Harvest and } \\
\text { post-harvest operations }\end{array}$ & $100 \%$ & $100 \%$ & $100 \%$ & $100 \%$ & $100 \%$ \\
\hline 6 & Equipment and tools & $92 \%$ & $72 \%$ & $72 \%$ & $92 \%$ & $82 \%$ \\
\hline 7 & $\begin{array}{l}\text { Distribution, traceability, } \\
\text { transportation }\end{array}$ & $41 \%$ & $74 \%$ & $74 \%$ & $74 \%$ & $66 \%$ \\
\hline 8 & $\begin{array}{l}\text { Human welfare, } \\
\text { health, and safety }\end{array}$ & $49 \%$ & $56 \%$ & $56 \%$ & $59 \%$ & $55 \%$ \\
\hline 9 & Record keeping & $44 \%$ & $67 \%$ & $67 \%$ & $57 \%$ & $59 \%$ \\
\hline & Overall Score & $58 \%$ & $81 \%$ & $81 \%$ & $73 \%$ & $73 \%$ \\
\hline
\end{tabular}

Survey sections with lower scores appear closer to the center of the circular graph in Figure 3. On average, cocoa farms showed the lowest overall scores in four sections of the survey. These were, in numerical order: Section 1-Premises and production site (33\%); Section 3-Use of agricultural inputs and chemicals 
(32\%); Section 7-Distribution, traceability, transportation (41\%); and Section 9-Record keeping (40\%).

Typically, the coffee farms were compliant or showed only minor non-compliance in all sections except for Section 8-Human welfare, health, and safety; and Section 9-Record keeping. This is in sharp contrast to the cocoa farms which showed minor to major levels of non-conformance in all but Section 4-Water Quality; Section 5-Harvest and post-harvest operations; and Section 6-Tools and equipment.

In Figure 4, the survey results for the eleven farms have been separated based on their affiliation or lack of affiliation with a cooperative. Three of the four coffee farms were part of a cooperative, while only one of the seven cocoa farms was a co-op member.

Figure 4 shows that overall audit scores of farms affiliated with a cooperative were higher (78\%) than those that were not co-op affiliated (55\%). The only exception to this trend was Section 6-Equipment and tools, where the cocoa farms showed very high scores even though only one of them was affiliated with a cooperative.

\subsection{Items by Category and Section}

The scores reflect the number of compliant items and non-conformance items (minor, major, and critical). Non-applicable (N/A) items have been removed from the scoring. A summary of the number of items falling into each level of compliance is presented for each farm in Table 5. Percentage scores have been included as a means of comparing their scores with the levels of conformance.

Table 5. Level of compliance by farm for 57 survey items.

\begin{tabular}{|c|c|c|c|c|c|c|c|}
\hline \multicolumn{2}{|c|}{ Farm Code } & \multirow{2}{*}{$\begin{array}{c}\text { Compliant } \\
11\end{array}$} & \multirow{2}{*}{$\begin{array}{c}\text { Minor } \\
11\end{array}$} & \multirow{2}{*}{$\begin{array}{c}\text { Major } \\
21\end{array}$} & \multirow{2}{*}{$\begin{array}{c}\text { Critical } \\
1\end{array}$} & \multirow{2}{*}{$\begin{array}{c}\mathrm{N} / \mathrm{A} \\
13\end{array}$} & \multirow{2}{*}{$\begin{array}{c}\% \text { Score } \\
59 \%\end{array}$} \\
\hline Cocoa & $\mathrm{CC} 01$ & & & & & & \\
\hline & $\mathrm{CC} 02$ & 11 & 11 & 21 & 1 & 13 & $59 \%$ \\
\hline & $\mathrm{CC03}$ & 5 & 8 & 21 & 3 & 20 & $48 \%$ \\
\hline & $\mathrm{CC} 04$ & 5 & 8 & 21 & 3 & 20 & $48 \%$ \\
\hline & $\mathrm{CC} 05$ & 6 & 6 & 16 & 3 & 26 & $50 \%$ \\
\hline & $\mathrm{CC} 06$ & 10 & 10 & 18 & 2 & 17 & $61 \%$ \\
\hline & $\mathrm{CC} 07$ & 7 & 9 & 17 & 0 & 24 & $61 \%$ \\
\hline \multicolumn{2}{|c|}{ Cocoa Average } & 7.9 & 9.0 & 19.3 & 1.9 & 19.0 & $55 \%$ \\
\hline \multirow[t]{4}{*}{ Coffee } & CF01 & 8 & 11 & 20 & 0 & 18 & $58 \%$ \\
\hline & CF02 & 25 & 15 & 8 & 1 & 8 & $81 \%$ \\
\hline & CF03 & 25 & 15 & 8 & 1 & 8 & $81 \%$ \\
\hline & CF04 & 14 & 13 & 10 & 0 & 20 & $73 \%$ \\
\hline \multicolumn{2}{|c|}{ Coffee Average } & 18.0 & 13.5 & 11.5 & 0.5 & 13.5 & $74 \%$ \\
\hline
\end{tabular}




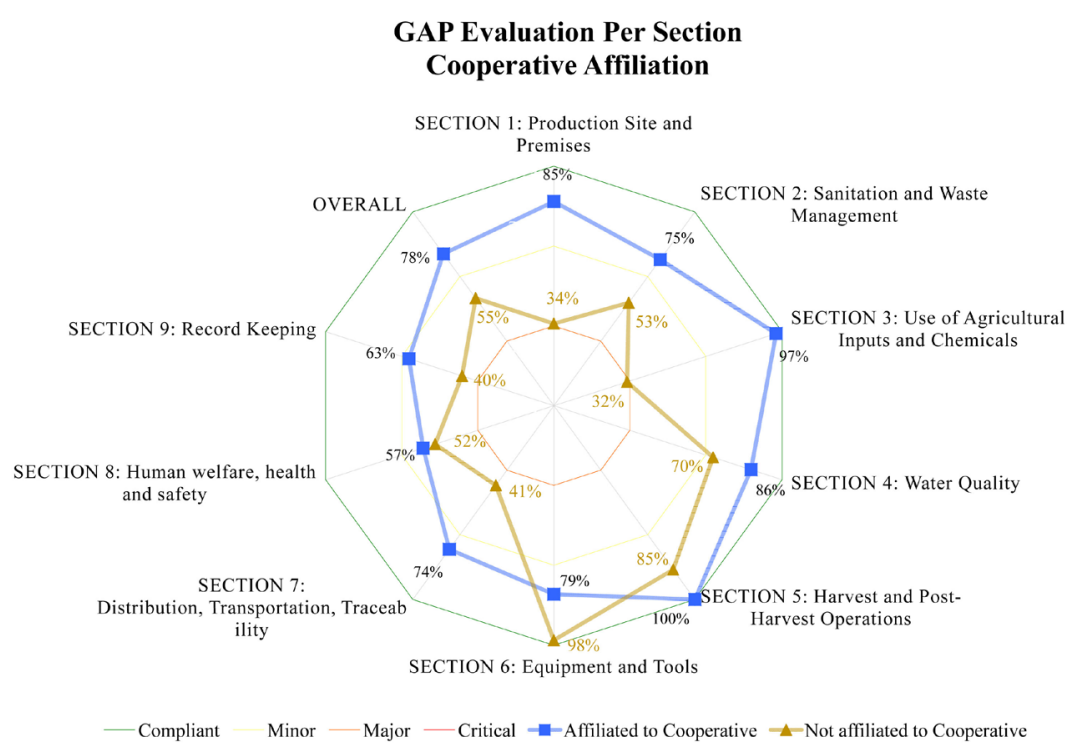

Figure 4. Comparison of audit scores per section and cooperative affiliation.

On average, coffee farms had more compliant items, with an average of 18.0 compliant items per farm compared to only 7.9 for the cocoa farms. The average number of minor non-conformance items was higher for the coffee farms (13.5) than for the cocoa farms (9.0). There was an average of 11.5 items in the major non-conformance category per coffee farm compared to 19.3 items per cocoa farm. Two of the four coffee farms had one critical non-compliant item which gave the coffee farms an average of 0.5 items in this category. Six out of the seven cocoa farms had at least one critical non-conformance item, for an average of 1.9 critical items per farm.

Table 6 provides a break-down of the levels of compliance by survey section.

Compliant Items: The section with most compliant items for all farms was Section 5 (Harvest and post-harvest operations) and the one with the least compliant items was Section 9 (Record keeping. It is noteworthy that in the case of the seven cocoa farms, there were no compliant items in Section 7-Distribution, transportation and traceability, and Section 9-Record keeping. Individual responses to each survey item have not been included here, in the interest of brevity.

Minor non-conformance items: The proportion of minor non-conformance items in each section was not more than $33 \%$ for all farms. Minor non-compliance items were evenly distributed throughout all sections for coffee farms, whereas cocoa farms had a high proportion of minor non-compliant items in Section 4 (Water quality) and Section 5 (Harvest and post-harvest operations). No minor non-conformances were observed in Section 5 for coffee farms.

Major non-conformance items: There was a great disparity in the proportion of major items in the sections of all farms. They were very low (i.e., lower than $10 \%$ in Sections 3, 4, 5 and 6) or very high (i.e., higher than $50 \%$ in Sections 1,7 and 8 ). In the case of cocoa farms, most sections had a higher proportion of 
Table 6. Distribution of compliance levels by section.

\begin{tabular}{|c|c|c|c|c|c|c|}
\hline \multicolumn{2}{|r|}{ Section } & \multirow{2}{*}{$\begin{array}{c}\text { Compliant } \\
10(18 \%)\end{array}$} & \multirow{2}{*}{$\begin{array}{l}\text { Minor } \\
5(9 \%)\end{array}$} & \multirow{2}{*}{$\begin{array}{c}\text { Major } \\
28(51 \%)\end{array}$} & \multirow{2}{*}{$\begin{array}{c}\text { Critical } \\
5(9 \%)\end{array}$} & \multirow{2}{*}{$\begin{array}{c}\text { N/A } \\
7(13 \%)\end{array}$} \\
\hline 1 & Production site and premises & & & & & \\
\hline 2 & $\begin{array}{c}\text { Sanitation and waste } \\
\text { management }\end{array}$ & $9(12 \%)$ & $16(21 \%)$ & $23(30 \%)$ & $1(1 \%)$ & $28(36 \%)$ \\
\hline 3 & $\begin{array}{l}\text { Use of agricultural inputs } \\
\text { and chemicals }\end{array}$ & $12(18 \%)$ & $2(3 \%)$ & $5(8 \%)$ & $3(5 \%)$ & $44(67 \%)$ \\
\hline 4 & Water quality & $18(27 \%)$ & $22(33 \%)$ & $4(6 \%)$ & $3(5 \%)$ & $19(29 \%)$ \\
\hline 5 & $\begin{array}{c}\text { Harvest and post-harvest } \\
\text { operations }\end{array}$ & $40(61 \%)$ & $14(21 \%)$ & $2(3 \%)$ & $0(0 \%)$ & $10(15 \%)$ \\
\hline 6 & Equipment and tools & $12(25 \%)$ & $5(9 \%)$ & $2(4 \%)$ & $0(0 \%)$ & $34(62 \%)$ \\
\hline 7 & $\begin{array}{l}\text { Distribution, traceability, } \\
\text { transportation }\end{array}$ & $6(11 \%)$ & $14(25 \%)$ & $32(58 \%)$ & $0(0 \%)$ & $3(5 \%)$ \\
\hline 8 & $\begin{array}{l}\text { Human welfare, } \\
\text { health, and safety }\end{array}$ & $13(20 \%)$ & $13(20 \%)$ & $34(52 \%)$ & $3(5 \%)$ & $3(5 \%)$ \\
\hline 9 & Record keeping & $5(4 \%)$ & $26(21 \%)$ & $51(42 \%)$ & $0(0 \%)$ & $39(32 \%)$ \\
\hline & Number of Items & 127 & 117 & 181 & 15 & 187 \\
\hline & Percentage of Total & $20 \%$ & $19 \%$ & $29 \%$ & $2 \%$ & $30 \%$ \\
\hline
\end{tabular}

major items than coffee farms. Also, major items in cocoa farms averaged $71 \%$ for Section 7 (Distribution, transportation and traceability), 60\% for Section 1 (Premises and production site) and $57 \%$ for Section 8 (Human welfare, health and safety). No major items were observed in coffee farms for Section 3 (Use of agricultural inputs and chemicals) or Section 5 (Harvest and post-harvest operations).

Critical non-conformance items: Critical non-conformance items had the largest impact on scores because no points were assigned to the specific item. On cocoa farms, critical non-conformance items were noted in Sections 1, 2, 3, 4 and 8. Section 1 (Premises and production site) had the largest proportion (14\%) of critical items, followed by Section 3 (Use of agricultural inputs and chemicals) and Section 4 (Water quality) with $7 \%$ critical items in each section. All critical non-conformances in coffee farms were identified in Section 8 (Human welfare, health and safety) concerning the lack of safeguards on equipment and around elevated surfaces (item 8.2), leading to a high risk of accidents in the processing area of the cooperative.

Non-Applicable Items: Table 6 shows that $30 \%$ of all items of the audit checklist were not applicable (N/A) to the farms audited. Section 3 (Use of agricultural inputs and chemicals) and Section 6 (Equipment and tools) had more than $60 \%$ of their items classified as N/A. In general, cocoa farms had more N/A items than coffee farms.

\subsection{Frequency of Items}

Each section was divided into specific items, having a total of 57 items in each 
audit checklist. The most frequent items for all farms appearing in each category are shown in Table 7.

Among the more frequent compliant items for all farms were the inspection of product before and during harvest (item 5.3) and the removal of extraneous materials and damaged product (item 5.4). Most farms were also compliant in inspecting the site prior to harvest (item 5.1). The most common minor issue in all

Table 7. The five most frequent items per compliance category for all eleven farms.

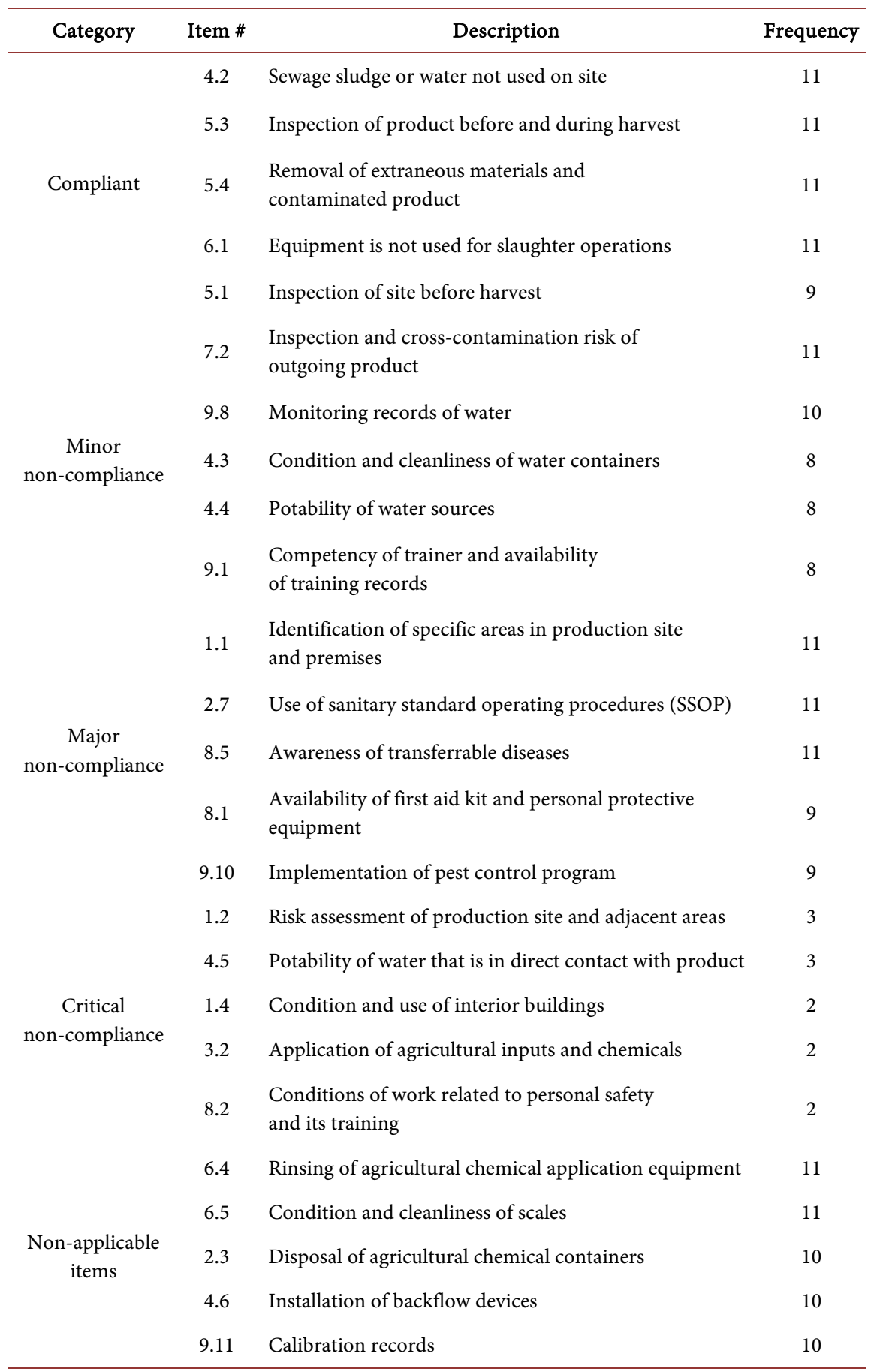


farms was the risk of cross-contamination of product at transportation (item 7.2). In the case of cocoa farms, improper storage of finished product (item 5.5), testing the potability of water sources (item 4.4), and keeping the test results for potability (item 9.8) were among the most frequent items. Coffee farms had frequent minor items regarding the sanitary design of equipment used (item 6.2), and lack of training records (item 9.1).

Major non-conformances were more frequent in the identification of areas of the production site and premises and the lack of designated areas for storage, equipment, chemicals and product (item 1.1), and the lack of cleaning instructions and cleaning practices (item 2.7). Cocoa farms frequently had more major issues in important areas such as traceability (items 7.3, 7.4 and 7.5), record keeping (items 9.3, 9.5 and 9.9) and lack of pest control programs (item 9.10). Coffee farms, however, had major issues in items related to human welfare, health and safety, specifically in the availability of first aid kits and personal protective equipment (item 8.1), and awareness of transferrable diseases to food (8.5).

Critical items were more frequent in cocoa farms than in coffee farms. The risk assessments of production site and premises (item 1.4) and adjacent areas (item 1.2) of cocoa farms were critical because no fences were observed and livestock animals and domestic pets had access to the production site plus processing and storage areas, and garbage was all over the farm. Other critical items in cocoa farms included washing of fresh cocoa beans to remove the mucilage with water that had not been treated or tested for potability (item 4.5), and the lack of control in the application of agricultural chemicals and harvest intervals (item 3.2) (Table 7). The only critical item found in coffee farms (item 8.2) has been addressed previously.

Table 7 reports that the most frequent non-applicable items for all farms were the cleaning of agricultural chemical application equipment (item 6.4), disposal of agricultural chemical containers (item 2.3), condition and cleanliness of scales (item 6.5) and calibration records (item 9.11).

\section{Discussion}

Poor scores in Section 1 (Premises and production site) are the reflection of the lack of fences installed, poor construction materials, garbage observed on the production site, and presence of livestock animals and domestic pets in farm and around the house. Cocoa farms had more of these major and critical non-conformances, where the main risk was that livestock was not contained in a pen, and dogs were running around where beans were processed or stored. More than 50\% of cocoa farmers had livestock in their farms (Table 3) but lacked good husbandry. It is of particular concern because animals can carry Salmonella spp., and a lack of segregated areas increases the risk of cross-contamination [25]. Permanent structures (e.g., farmers' houses) tended to be of poor construction and were not ideal to store finished product. Unfortunately, in the case most farmers in this 
assessment, it was an unavoidable reflection of their economic situation. Coffee farms that were affiliated with a cooperative scored higher in Section 1 (range from $78 \%$ to $89 \%$ ) because farmers did not have livestock on site (Table 3 ). They brought their harvest to the cooperatives, which were cleaner and had decent permanent structures with fences and walls to keep animals away. This suggests that being part of a cooperative could help reduce risks related to premises, considering that they are in good conditions.

Sanitation and waste management practices varied widely (33\% to $81 \%$ conformance) among the cocoa and coffee farms, which was cause for concern. Items related to the disposal of chemical containers were more frequently "N/A" since most farms do not use agricultural chemicals. The lack of waste disposal containers and specific cleaning procedures were among the most frequent non-conformances on the farms. Garbage was disposed on production sites or it was burnt regularly. The presence of garbage and abandoned equipment observed on site promoted the harboring of pests. Samapundo et al. [9] found similar conditions among street vendors in Haiti, where they would dispose of garbage and leftovers beside the stall, attracting flies and animals. CC05 had a critical non-conformance because the outhouse was located between the house and the farm, and standing water was observed at the access of the farm, which indicated a fault in the septic system. Since Salmonella spp. are transmitted through the fecal-oral route, domestic pets and people could step in the standing water and cross-contaminate processing and storage areas, exposing the product to a high risk.

The section that showed to be less applicable to the farms assessed was Section 3 (Use of agricultural inputs and chemicals) because not all of the farmers used fertilizers or pest control products. All items of Section 3 were not applicable to 6 farms (Table 4(a) and Table 4(b)), deeming the whole section "N/A". The farms that used agricultural chemicals either scored low (i.e., cocoa farms) because of the lack of control in the application, insufficient training and purchase from questionable suppliers, or scored high (i.e., coffee farms) because they exported "Certified Organic" product and the cooperative provided adequate training. Pests and diseases have a direct impact on yields and profits [35]. Therefore, farmers should consider the use of agricultural chemicals, focus on resistant varieties, or follow stringent practices to prevent, control and eliminate pest and diseases [36]. Similar results were reported in a study among cocoa farmers in Ghana, where most farmers did not spray their farm with pesticides because it was an expensive practice [35]. Other challenges of using agricultural chemicals are the use of banned or unapproved chemicals, inefficient application, and lack of training and monitoring activities [35] [37]. On the other hand, not using agricultural chemicals on the farms assessed could be seen as reducing the risk of pesticide residues in the finished product and lowering risks to the health and safety of workers. In addition, there is a niche market for "sustainable" products with a growing trend in cocoa and coffee products [18] and sev- 
eral certifications like "Certified Organic", "Rain Forest Alliance", "UTZ" and "Fair Trade" are commonly used in these cases.

Regarding water quality, it was found that farmers relied on rain for their crops, as there were no irrigation systems on any farm visited. They also accessed water from rivers, natural springs, or private wells. None of the rivers were accessed by the farmers in this survey because farmers mentioned that the rivers were far from their farms. However, downstream contamination was observed as people bathed, washed their clothes and refreshed their animals. Private wells were out in the open, few of them were fenced, and all had manual pumps to bring the water up. As stated previously [5], it is estimated that less than $70 \%$ of the population in Haiti has access to potable water sources. This was difficult to verify because neither the farmers nor the cooperatives conducted potability tests. In most cases, such items were classified as minor non-conformances. Item 4.5, concerning the use of potable water, was one of the two most frequent non-conformances in cocoa farms because some farmers rinsed the cocoa beans after breaking the pod to remove the mucilage, speed up the drying process, and sell the beans sooner. By doing so, the fermentation of beans would not take place and, most important for this section, the finished product would have been rinsed with water of questionable potability. Cocoa is considered a cash crop because it has no "subsistence value" to the household [38] and when farmers have income problems, they tend to compromise the quality of the product to get cash quicker [37]. It certainly was the case in this study, where $91 \%$ of participant's income came from sources other than farming (Table 1).

Section 5 (Harvest and post-harvest operations) received the highest scores in all farms. Scores ranged from $70 \%$ to $100 \%$, and all coffee farms scored $100 \%$. Table 2 shows that farmers are generally male, older, and have many years of farming experience. The population demographics of the sample were similar to other studies in Trinidad [31] and Ghana [35] [37], where farmers had more knowledge on harvesting practices, and experience tended to be a reason for high scores. It is important to mention that the audit matrix did not contain specific items related to fermentation steps because it was designed for small farms harvesting any tree or vegetable crop.

High scores in Section 6 (Equipment and tools) were a combination of compliant items and "N/A" items (Table 6). Also, this section was the only one in which cocoa farms scored higher than coffee (Figure 3 ). This could be explained because cocoa farmers only used their machetes to harvest and process, whereas coffee farmers used a wooden mortar and pestle or diesel-operated grinders.

Distribution, transportation and traceability practices faced several challenges. Interestingly enough, farms that were affiliated with a cooperative averaged $74 \%$ against $41 \%$ that were not affiliated (Figure 4). Farmers not affiliated with a cooperative stored their product at home and either waited for a cooperative to come and buy it from them, or they would send the product to a market or association. Three types of transportation were observed: by animal, usually a mule 
or donkey; by public transit, where loads were put on top of the vehicle; or by truck which carried several different types of loads per trip. In general, all of those means of transportation exposed the finished product to environmental elements such as dust, rain, or extreme heat. In general, vehicles were not well maintained. Farmers did not identify their fields and harvested product, nor did they keep records of their farming activities, which makes it challenging for traceability purposes. Traceability systems are important for maintaining low levels of pesticide residues, heavy metals, and mycotoxins [36]. For the chocolate industry, it has been suggested that traceability systems could be useful beyond legal implications of food safety, such as flavour profile and better selection of cultivars [39]. Being a member of a cooperative helped having better records and proper lot identification of the product, as Figure 4 shows high scores in Section 7 (Distribution, transportation and traceability).

There was not much awareness among participants related to health and safety practices. For instance, there was no first aid kit or personal protective equipment available. There was no awareness of transferrable diseases to food, problems associated with the lack of running water, and the implications of poor hygiene practices. Often, toilets and hand washing stations were not fully equipped. Similar attitudes and practices among street vendors in Haiti were reported by Samapundo et al. [9]. The only critical item among coffee producers was in Section 8 (Human welfare, health and safety) because of a lack of safeguards on equipment and elevated surfaces within processing areas. When the coffee cherries were received, they were put in a basin where the good ones will sink and the bad ones will float and be discarded. The good coffee cherries were then transported in buckets by hand to a higher basin. No railings were observed here, even though the height was more than $3 \mathrm{~m}$, and the edge of the basin was no wider than $90 \mathrm{~cm}$. The operator that controls the feed of cherries to the grinder would stand in front of it on a very unstable surface, and the equipment had no safeguards. Awareness is needed to minimize risks of accidents and job injuries. One of the benefits of following GAPs is the improvement of hygiene, health and safety of workers [16].

It was expected that Section 9 (Record keeping) would have one of the lowest scores of the audit (47\%). Most farmers did not record training, cleaning or harvesting activities, and water treatments. Most had no visitors' policies nor pest control programs in place. The two coffee farms that exported green coffee beans (CF02 \& CF03) had a visitors' policy and pest control program in place because they had been audited before. Record keeping was definitely a challenge for small-scale farmers [15].

\section{Conclusions}

There was a low level of compliance of good agricultural practices (GAPs) among cocoa farmers, and a moderate level among coffee farmers. The root cause of the non-conformances, regardless of the commodity, was either related 
to poor physical and organizational infrastructures, or a lack of technical training. A factor that seemed to improve the level of compliance of GAPs was affiliation with a cooperative which tended to provide training to its members. Cooperative members had premises that were in better conditions than the farmer's house, and kept more records than the individual farmers who were not associated with a cooperative.

While some of the issues addressed in this study could be corrected by a change of attitude of the farmer, or by simple adjustments in the farm, most of them would require a more complex approach involving several stakeholders in the value chain to address the root cause. Immediate corrective actions are needed in areas related to crop protection and water potability, plus health and safety of workers. Basic literacy improvements would facilitate the implementation of GAPs as producers and visitors would more easily be able to adhere to processes that would be readily accessed and understood.

The original intent of this study was to assess the status of Good Agricultural Practices (GAPs) in cocoa and coffee farms in Northern Haiti, as well as identifying the most common practices that would compromise the food safety and quality of Haitian cocoa and coffee beans. Unfortunately, this project had certain limitations. The number of farms available for the study was limited, as well as the time and resources allocated to conduct a thorough audit of each farm. Due to such restrictions, it would not be reasonable to extrapolate the findings and generalize the status of GAPs in Haiti. However, results presented here should be interpreted in the context of the Haiti Food Hub farms and used as a starting point for addressing food safety issues in Haiti. The improvement of quality and marketability of the Haitian farmer's products would make an impact on the Long Term Sustainability of Farms and the rural communities of Haiti.

Despite the limitations mentioned above, this research project has provided the first step to understand and effect positive development for the cocoa and coffee producers of Haiti, and the people of that nation in general. These results have been communicated to the Haiti Food Hub agronomist and will be used as a metric from which to gauge future progress in the identified areas of concern and non-compliance.

\section{Acknowledgements}

The authors are grateful to Jennifer van Steenkiste, Gerard Michel Joseph, and Widley Presendieu of the Haiti Food Hub (HFH) for their assistance in coordinating the activities in Haiti, recruiting participants, and serving as guides and translators during the time the surveys were conducted.

\section{Funding}

This research was funded by a Guelph Food Technology Centre (GFTC) Legacy Fund award. 


\section{Author Contributions}

The three authors of this paper worked as a close-knit group with a high level of involvement through all aspects of the research project. The following is a summary of their contributions. Abraham Navarro was a graduate student in the Food Safety and Quality Assurance (FSQA) Master's Degree Program in the Department of Food Science at the University of Guelph. This study constituted his Master's Degree project. Abraham was the primary researcher, and conducted on-the-ground activities in Haiti. He prepared the initial project report as part of the requirements for his Master's Degree. Prof. Elliott Currie of the Department of Management, in the College of Business and Economics at the University of Guelph was the co-advisor on this project. He has done substantial work with the Haiti Food Hub through his team of graduate students. As a result, Prof. Currie has a great deal of insight into the state of affairs with agriculture in Haiti. Dr. Don Mercer of the Department of Food Science, in the Ontario Agricultural College at the University of Guelph was the student's graduate supervisor. In this capacity, he had responsibilities for all aspects of the project, including the procurement of permission of the University of Guelph Research Ethics Board to conduct the research project. Dr. Mercer has had a great deal of experience in international activities pertaining to food processing and training of agricultural workers.

\section{Conflicts of Interest}

The authors declare no conflict of interest. The Guelph Food Technology Centre (GFTC) Legacy Fund which provided financial sponsorship for this project had no role in the design of the study; in the collection, analyses, or interpretation of data; in the writing of the manuscript; nor in the decision to publish the results.

\section{References}

[1] United Nations Development Programme (UNDP) (2017) Human Development Report 2017. http://hdr.undp.org/en/countries/profiles/HTI

[2] World Bank (2014) Haiti. Countries. http://www.worldbank.org/en/country/haiti/overview

[3] World Food Program (WFP) (2018) Haiti. Countries. http://www1.wfp.org/countries/haiti

[4] World Bank, Sustainable Energy for All (SE4ALL) Database from the SE4ALL Global Tracking Framework (2018). https://data.worldbank.org/indicator/EG.ELC.ACCS.ZS

[5] Sentlinger, K. (2018) Water in Crisis-Haiti. https://thewaterproject.org/water-crisis/water-in-crisis-haiti

[6] Central Intelligence Agency (CIA) (2013) Central America and Caribbean: Haiti. The World Factbook 2013-14. https://www.cia.gov/library/publications/the-world-factbook/geos/ha.html

[7] Government of Canada (2018) Canada's International Assistance in Haiti. http://international.gc.ca/world-monde/issues_development-enjeux_developpemen 
t/priorities-priorites/where-ou/haiti.aspx?lang=eng

[8] Observatory of Economic Complexity; OEC-Haiti (HTI) Exports, Imports, and Trade Partners (2016). https://atlas.media.mit.edu/en/profile/country/hti/

[9] Samapundo, S., Climat, R., Xhaferi, R. and Devlieghere, F. (2014) Food safety Knowledge, Attitudes and Practices of Street Food Vendors and Consumers in Port-au-Prince, Haiti. Food Control, 50, 457-466. https://doi.org/10.1016/j.foodcont.2014.09.010

[10] Fredrickson, N. (2015) Global food defense: Port-au-Prince Haiti [Blog Post]. https://foodprotection.umn.edu/news/post/global-food-defense-port-au-prince-haiti

[11] Schwartzbord, J.R., Emmanuel, E. and Brown, D.L. (2013) Haiti's Food and Drinking Water: A Review of Toxicological Health Risks. Clinical Toxicology, 51, 828-833. https://doi.org/10.3109/15563650.2013.849350

[12] Grandesso, F., Allan, M., Jean-Simon, P.S., Boncy, J., Blake, A., Pierre, R., et al. (2014) Risk Factors for Cholera Transmission in Haiti during Inter-Peak Periods: Insights to Improve Current Control Strategies from Two Case-Control Studies. Epidemiology and Infection, 142, 1625-1635. https://doi.org/10.1017/S0950268813002562

[13] Food and Agriculture Organization (FAO) of the United Nations. (2003) Development of a Framework for Good Agricultural Practices. Committee on Agriculture (COAG), Rome. http://www.fao.org/docrep/meeting/006/y8704e.htm

[14] Global Food Safety Initiative (GFSI) (2020) Global Food Safety Initiative Recognition. https://mygfsi.com/how-to-implement/recognition/

[15] Hansen, H. and Trifković, N. (2014) Food Standards Are Good-For Middle-Class Farmers. World Development, 56, 226-242.

https://doi.org/10.1016/j.worlddev.2013.10.027

[16] Handschuch, C., Wollni, M. and Villalobos, P. (2013) Adoption of Food Safety and Quality Standards among Chilean Raspberry Producers-Do Smallholders Benefit? Food Policy, 40, 64-73.

[17] Schillhorn, V.V. and Tjaart, W. (2005) International Trade and Food Safety in Developing Countries. Food Control, 16, 491-496.

https://doi.org/10.1016/j.foodcont.2003.10.014

[18] International Cocoa Organization (ICCO) The World Cocoa Economy-Past and Present (2010).

https://www.icco.org/about-us/international-cocoa-agreements/cat_view/30-related -documents/45-statistics-other-statistics.html

[19] Haffner, R. (2012) Future Global Coffee Trends. Article. Coffee and Tea International Business Magazine, 2, 30-31.

https://issuu.com/coffeetea/docs/coffee_tea_international_2-2012_en-free

[20] International Coffee Organization (ICO) (2015) Coffee Market Report [Blog Post]. http://icocoffeeorg.tumblr.com/post/116383112905/coffee-market-settles-lower-but -demand

[21] World Cocoa Foundation (WCF) (2014) Cocoa Market Update. Uploads. http://worldcocoafoundation.org/wp-content/uploads/Cocoa-Market-Update-as-of4-1-2014.pdf

[22] Canadian Food Inspection Agency (CFIA) (2014) Food Safety Practices Guidance for Moulded Chocolate Manufacturers.

http://www.inspection.gc.ca/food/safe-food-production-systems/haccp-generic-mo dels-and-guidance-documents/guidance-moulded-chocolate/eng/1362163599079/1 
362164529664?chap $=1$

[23] Codex Alimentarius International Food Standards (2013) Code of Practice for the Prevention and Reduction of Ochratoxin A Contamination in Cocoa. Reference CAC/RCP 72-2013.

http://www.fao.org/fao-who-codexalimentarius/codex-texts/codes-of-practice/en/

[24] Food and Drug Administration (FDA) (2012) Bad Bug Book: Handbook of Foodborne Pathogenic Microorganisms and Natural Toxins Handbook. 2nd Edition, FDA, Center for Food Safety and Applied Nutrition, Washington DC.

https://www.fda.gov/downloads/Food/FoodborneIllnessContaminants/UCM297627 $\underline{\text { pdf }}$

[25] Nascimento, M.S., Pena, P.O., Brum, D.M., Imazaki, F.T., Tucci, M.L.S. and Efraim, P. (2013) Behavior of Salmonella during Fermentation, Drying and Storage of Cocoa Beans. International Journal of Food Microbiology, 167, 363-368. https://doi.org/10.1016/j.ijfoodmicro.2013.10.003

[26] Badrie, N., Bekele, F., Sikora, E. and Sikora, M. (2015) Cocoa Agronomy, Quality, Nutritional, and Health Aspects. Critical Reviews in Food Science and Nutrition, 55, 620-659. https://doi.org/10.1080/10408398.2012.669428

[27] Copetti, M.V., Pereira, J.L., Iamanaka, B.T., Pitt, J.I. and Taniwaki, M.H. (2010) Ochratoxigenic Fungi and Ochratoxin A in Cocoa during Farm Processing. International Journal of Food Microbiology, 143, 67-70. https://doi.org/10.1016/j.ijfoodmicro.2010.07.031

[28] Copetti, M.V., Iamanaka, B.T., Pitt, J.I. and Taniwaki, M.H. (2014) Fungi and Mycotoxins in Cocoa: From Farm to Chocolate. International Journal of Food Microbiology, 178, 13-20. https://doi.org/10.1016/j.ijfoodmicro.2014.02.023

[29] Copetti, M.V., Iamanaka, B.T., Nester, M.A., Efraim, P. and Taniwaki, M.H. (2013) Occurrence of Ochratoxin A in Cocoa By-Products and Determination of Its Reduction during Chocolate Manufacture. Food Chemistry, 136, 100-104. https://doi.org/10.1016/j.foodchem.2012.07.093

[30] Oliveira, G., Da Silva, D.M., Peireira, R.G.F.A., Paiva, L.C., Prado, G., and Batista, L.R. (2013) Effect of Different Roasting Levels and Particle Size on Ochratoxin A Concentration in Coffee Beans. Food Control, 34, 651-656. https://doi.org/10.1016/j.foodcont.2013.06.014

[31] Ganpat, W., Badrie, N., Walter, S., Roberts, L., Nandlal, J. and Smith, N. (2014) Compliance with Good Agricultural Practices (GAPs) by State-Registered and Non-Registered Vegetable Farmers in Trinidad, West Indies. Food Security, 6, 61-69. https://doi.org/10.1007/s12571-013-0322-4

[32] Canada GAP (2014) Food Safety Manual for Fresh Fruits and Vegetables (Version 6.2) Manuals. Updated Version 7.1. https://www.CanadaGAP.ca/manuals/downloads/

[33] Food and Agriculture Organization (FAO) of the United Nations (2007) Good Agricultural Practices for Family Agriculture Guidelines. FAO Regional Office for Latin America and the Caribbean. http://www.fao.org/docrep/010/a1193e/a1193e00.htm

[34] Canada GAP (2014) Appendices to Canada GAP Food Safety Manuals (Version 6.2) Manuals. Updated Version 7.1.

http://www.bcveg.com/docs/foodsaftey/CanadaGAP-Appendices-7.1-2018-ENG\%2 0Final.pdf

[35] Anang, B.T., Fordjour, E. and Boateng, V.F. (2011) Farmers' Management Practices 
and the Quality of Cocoa Beans in Upper Denkyira district of Ghana. Asian Journal of Agricultural Sciences, 3, 487-491.

[36] International Cocoa Organization (ICCO) (2009) Guidelines on Best-Known Practices in the Cocoa Production. Consultative Board on the World Cocoa Economy, Moscow.

https://www.icco.org/about-us/international-cocoa-agreements/cat_view/30-related -documents/32-consultative-board-on-the-world-cocoa-economy.html

[37] Quarmine, W., Haagsma, R., Sakyi-Dawson, O., Asante, F., Van Huis, A. and Obeng-Ofori, D. (2012) Incentives for Cocoa Bean Production in Ghana: Does Quality Matter? NJAS - Wageningen Journal of Life Sciences, 60-63, 7-14. https://doi.org/10.1016/j.njas.2012.06.009

[38] Perdew, J.G. and Shively, G. (2009) The Economics of Pest and Production Management in Small-Holder Cocoa: Lessons from Sulawesi. Bulletin of Indonesian Economic Studies, 45, 373-389. https://doi.org/10.1080/00074910903416288

[39] Saltini, R., Akkerman, R. and Frosch, S. (2013) Optimizing Chocolate Production through Traceability: A Review of the Influence of Farming Practices on Cocoa Bean Quality. Food Control, 29, 167-187.

https://doi.org/10.1016/j.foodcont.2012.05.054 


\section{Appendix A}

\section{Audit Questions-Assessment of Good Agricultural Practices in Haiti}

See audit scoring matrix for the severity of each item

\section{General Information}

o Name

○ Company

○ Telephone

○ Email

O Type of consent (written, oral)

\section{Farmer Information}

- Gender (male, female)

$\bigcirc$ Age ( $<18$ years, 19 - 30 years, $31-45$ years, $>45$ years)

$\bigcirc$ Farming experience (<5 years, 5 - 10 years, 11 - 20 years, 21 - 30 years, $>30$ years)

- Education Level (none, elementary school, middle school, high school, other)

- Has farmer received any agricultural training? Y/N (Specify)

○ Number of household members, including farmer $(1-2,3-5,6-8,9$ or more)

Does household income come only from farming activities? Y/N

\section{Farm Information}

- Region and nearest city or town

- Crop of interest (cocoa or coffee; specify the variety)

○ Farm size (<1 ha, 1 - 5 ha, 5 - 10 ha, <10 ha)

○ Harvest yield

O Is the farm affiliated to a cooperative? Y/N (specify)

- Land status (owned, leased, rented, other)

- Export status (exported, not an exporter)

O Certification in place? Y/N (specify)

Other crops harvested in the same farm (tree crops, vegetables, root crops)

O Are livestock animals present in the farm? Y/N (specify)

1) Section 1-Production Site and Premises

a) There is a layout of the production site and premises, which identifies: Equipment, operations, storage, personal hygiene facilities, waste disposal containers, water sources hand washing stations, pest control devices.

b) Adjacent areas to production sites have no risk of cross-contamination from crop inputs (e.g., fertilizer and/or agricultural chemicals) or other contaminants (e.g., air, water or soil), have proper drainage and no standing water was observed. NOTE: Follow assessment form.

c) Permanent structures are constructed with doors and windows that fit, and without crevices, holes or leaks in walls or ceiling; the surroundings areas are kept clean to discourage harboring of pests (garbage, long grass, unused equipment).

d) Interior buildings are clean, without access to animals (domestic or wild) 
and no signs of pests are observed; not used for slaughter; lighting is adequate and protected where product is handled; has adequate drainage, pipes are not leaking and there is no risk of condensation.

e) An area is dedicated for breaks and lunch, and is separate from areas where product is handled, and another area for storing personal belongings.

2) Section 2-Sanitation and Waste Management

a) Sufficient waste disposal containers are located throughout the production site and interior buildings. They do not pose a risk for finished product, water sources, packaging materials or compost. They are covered where pest or animals can have access to them, and identified according to the type of waste (i.e., recycling, garbage or compost)

b) Garbage is taken out when containers are full; they are cleaned at least once a month in a separate area that would not pose a risk of cross contamination.

c) Before discarding agricultural chemical containers, they are rinsed at least 3 times; containers are not reused and are disposed according to local regulations.

d) Toilet waste and from hand washing stations is not disposed in production site but into a septic system, municipal sewage or through a service provider (i.e., portable toilet company).

e) Cleaning and maintenance materials are used according to manufacturer's instructions and are stored separate from other products (agricultural chemicals, product, packaging materials) in a dry and clean location, with a label that identifies them and in a manner that the container is not damaged.

f) Bait, damaged traps, glue boards and pests are disposed in a sealed container and put in the garbage; the person monitoring pest control devices washes hands after handling them.

g) There are sanitation standard operating procedures (SSOP) in place, which describe the cleaning instructions of premises, equipment and tools, and the appropriate concentration of detergents and sanitizers.

3) Section 3-Use of Agricultural Inputs and Chemicals

a) Agricultural inputs (e.g., fertilizers, sludge, manure, compost, soil amendments, mulch) are bought from reputable sources. The type (e.g., cattle) and origin (i.e., produced under proper conditions) of manure is known. Compost is produced under conditions that do not pose a risk of biological, physical or chemical contamination.

b) Application of fertilizers, sludge and soil amendments are applied according to instructions or expert advice. Manure is spread at least 120 days before harvest. Compost is applied at any time.

c) Agricultural chemicals are approved for use and comply with local regulations. They are only bought from licensed suppliers. Containers are not damaged, are properly identified (e.g., name, active ingredient, concentration, PCP\#, manufacturer name and contact info, instructions).

d) Fertilizers, sludge, soil amendments and mulch are stored separate from product and packaging materials, in a covered, clean, dry location, with a label 
that clearly identifies them. Manure and compost are stored away from water sources and where drifting or leaching is not a risk. Agricultural chemicals are stored in a secure location (e.g., locked cabinet), clean, dry location, with a label that clearly identifies them.

e) Those who apply the agricultural chemicals are properly trained or supervised by someone formally trained and follow recommended instructions.

f) There is a Pest Control Program in place (either by a third-party or self-managed) where bait is not used inside buildings, pest control chemicals are approved for use according to local regulations, pest control devices are labeled and identified in a layout.

4) Section 4-Water Quality

a) Water sources (e.g., private well, surface water, municipal water) are assessed for potential risks (e.g., upstream contamination, animal access, sewage, runoff of agronomic inputs) at least once a year, and preventive or corrective measures have been implemented where needed (e.g., fences, vegetative buffer zones, water tests). NOTE: Follow assessment form

b) Sewage sludge or sewage water is not used on site. Sewage or tertiary water is not used for activities where it is in contact with the product (e.g., cleaning, fluming, cooling, drenching). If there is a contamination alert of the water source, it is not used.

c) Tanks, containers or cisterns are cleaned before their first use as storage receptacles of water, and ensures they are in operating conditions (i.e., with lid, no evidence rust or leakage).

d) Water sources are tested for total coliforms and E. coli at least once prior use and once during season from all sources (except municipal water). Strongly suggested for agricultural water (i.e., used for irrigation and preparing solutions of fertilizers and chemicals), and mandatory for water that is in contact with product (i.e., cleaning, fluming, cooling, drenching).

e) Water used for cooling, drenching, fluming or washing product, and misting, cleaning operations comes from a potable source and is either kept potable or the product gets a final rinse with potable water. If water is treated for potability (i.e., with chlorine or any other alternative method), it is done following a validated procedure, $\mathrm{pH}$ and chlorine concentration is monitored.

f) Backflow prevention devices are in place where water is used for agricultural chemical application.

5) Section 5-Harvest and Post Harvest Operations

a) Before harvest, the production site is inspected to make sure there are no signs of obvious contamination (flooding, wildlife, chemical spills).

b) Product is harvested only after 120 days (minimum) from the time manure was spread, and the pre-harvest interval (PHI) has passed.

c) Product is visually inspected before and during harvest; product does not have obvious signs of contamination, and packaging materials are not source of contamination to the product; fruits and vines that have fallen on the ground are 
not harvested.

d) Foreign objects and crop debris are removed; damaged product or with obvious signs of contamination is discarded.

e) Product is stored in a clean area, separate from equipment, agronomical chemicals, cleaners, etc.

f) Packaging materials are clean and free of debris, and are not used for any other purposes (carrying tools, chemicals, personal effects, etc.); are kept off the ground and walls $(8 \mathrm{~cm})$; reusable porous materials have an impermeable liner, and non-porous materials are cleaned before used.

6) Section 6-Equipment and Tools

a) Equipment is not used for slaughter operations

b) Equipment and tools that have contact with food are easy to clean, made out of non-porous materials, and are not a potential source of contamination. They are located or installed where there is sufficient space between floors and walls that allows easy cleaning, and stored in a manner that avoids cross-contamination of product or water sources.

c) Equipment is inspected before its use. Equipment (agricultural chemical applicator, spreaders, scales, thermometers, $\mathrm{pH}$ meter, chlorinator, etc.) is calibrated according to the manufacturer's instructions at the beginning of the season, when important parts are replaced or when inspection indicates its need.

d) Agricultural chemical application equipment is flushed or rinsed in between applications and in a way that water sources or production site is not contaminated.

e) Cross contamination is avoided by dedicating cloths for wiping product only, and cleaning scales in between use of weighing agricultural chemicals and product.

7) Section 7 -Distribution, Transportation and Traceability

a) The cargo area of the vehicle that will transport the product is inspected for cleanliness, is free of pests (or evidence of infestation) and well maintained. The vehicle is constructed in a way that environment elements will not contaminate the load, or that a protective covering (e.g., tarp, plastic wrap) secures the load.

b) Outgoing product is inspected before loading it into the vehicle. When product is loaded, it is placed in a manner that it does not come in contact with other materials that have the potential risk of cross-contamination (e.g., allergens, livestock, agricultural chemicals).

c) Shipments are recorded (e.g., date, product description and ID, quantity, vehicle inspection, carrier, destination, customer and person responsible).

d) Identification of harvested product is done by using pallet tag, bin tags or other form of identification. Those pallets or bin tags are linked to date of harvest and block or field\#. Outgoing product leaves the premises with an ID\#/Lot\#.

e) It is possible to trace back how and when the outgoing shipment was grown, treated with agricultural chemicals, harvested, processed and stored by referring to records kept. 


\section{8) Section 8-Human Welfare, Health and Safety}

a) A first aid kit is available and in good condition. Emergency phone numbers (fire brigade, police, hospital) are at hand. Personal protection equipment (e.g., goggles, rubber gloves, rubber boots, masks, aprons) is available, clean and in good condition.

b) Workers are trained in the use of agricultural chemicals (e.g., pesticides), agricultural inputs (e.g., fertilizers, manure) and equipment. Workers are trained in practices related to food safety, personal hygiene and specific to the job. Training is done by a competent/certified person.

c) Training is provided to employees before the season, to new employees, when good practices need to be reinforced. Training is provided in a language that the employee understands.

d) Children do not participate in farming activities. They may help in family farming activities only if such activities do not interfere with school activities and do not attempt against their safety.

e) Workers are aware of transferrable diseases to food (e.g., Hepatitis A, salmonella, E. coli). When showing signs of disease, the person seeks medical attention as soon as possible, and is removed from activities that may contaminate the product (e.g., handling fresh product). Bandaged wounds are covered with waterproof materials (e.g., rubber gloves).

f) Toilets and hand washing facilities are available, clean, easily accessible and fully equipped (toilet paper, soap, paper towels, hand wipes, hand sanitizer, garbage). There are signs that remind users to wash hands after using the toilet.

\section{9) Section 9-Record Keeping}

a) Person responsible for training demonstrates he/she is competent. Certificates (when needed) are available and up-to-date. Worker's training is recorded and records are available.

b) Health records are kept confidential

c) There is a policy in place where it establishes the controlled areas (as to prevent contamination of the product), visitors are accompanied at all times during the visit of controlled areas, visitors read the policy and sign in a log book before accessing to controlled areas.

d) Cleaning and maintenance materials (detergents, sanitizers, inks, lubricants, food additives, processing aids) are bought from reputable sources. MSDS and letter of no-objection (when required) are kept in file.

e) Toilet and hand washing facilities are cleaned regularly (daily in peak season) and such activities are recorded.

f) There is a list of agricultural chemicals used on site; technical data sheets (TDS) and material safety data sheets (MSDS) are kept on file.

g) The applications of agricultural inputs (e.g., fertilizers, sludge, manure, compost, soil amendments, mulch) and chemicals (e.g., pesticides, herbicides, fungicides) are recorded, including application date, area treated, person responsible, quantity applied, PHI/DAA, etc. Records are available. 
h) Water treatment is monitored regularly and recorded.

i) Harvesting information (product, variety, PHI/DAA, harvest date, quantity, block\# or bin tag, type of packaging material used, storage date) is recorded and available.

j) Pest Control Product Numbers (PCP\#), applications and findings are recorded. Corrective actions are taken when there is a trend or pattern that show pest populations increasing.

k) Calibration records of equipment are available.

\section{Appendix B}

\section{Audit Questions-Assessment of Good Agricultural Practices in Haiti}

A scoring matrix was constructed based on the following nine sections. A severity ranking for each item was assigned to each item.

1) Section 1-Production Site and Premises

a) There is a layout of the production site and premises, which identifies: Equipment, operations, storage, personal hygiene facilities, waste disposal containers, water sources hand washing stations, pest control devices.

b) Adjacent areas to production sites have no risk of cross-contamination from crop inputs (e.g., fertilizer and/or agricultural chemicals) or other contaminants (e.g., air, water or soil), have proper drainage and no standing water was observed. NOTE: Follow assessment form.

c) Permanent structures are constructed with doors and windows that fit, and without crevices, holes or leaks in walls or ceiling; the surroundings areas are kept clean to discourage harboring of pests (garbage, long grass, unused equipment).

d) Interior buildings are clean, without access to animals (domestic or wild) and no signs of pests are observed; not used for slaughter; lighting is adequate and protected where product is handled; has adequate drainage, pipes are not leaking and there is no risk of condensation.

e) An area is dedicated for breaks and lunch, and is separate from areas where product is handled, and another area for storing personal belongings.

2) Section 2-Sanitation and Waste Management

a) Sufficient waste disposal containers are located throughout the production site and interior buildings. They do not pose a risk for finished product, water sources, packaging materials or compost. They are covered where pest or animals can have access to them, and identified according to the type of waste (i.e., recycling, garbage or compost)

b) Garbage is taken out when containers are full; they are cleaned at least once a month in a separate area that would not pose a risk of cross contamination.

c) Before discarding agricultural chemical containers, they are rinsed at least 3 times; containers are not reused and are disposed according to local regulations.

d) Toilet waste and waste from hand washing stations are not disposed in production site but into a septic system, municipal sewage or through a service 
provider (i.e., portable toilet company).

e) Cleaning and maintenance materials are used according to manufacturer's instructions and are stored separate from other products (agricultural chemicals, product, packaging materials) in a dry and clean location, with a label that identifies them and in a manner that the container is not damaged.

f) Bait, damaged traps, glue boards and pests are disposed in a sealed container and put in the garbage; the person monitoring pest control devices washes hands after handling them.

g) There are sanitation standard operating procedures (SSOP) in place, which describe the cleaning instructions of premises, equipment and tools, and the appropriate concentration of detergents and sanitizers.

3) Section 3-Use of Agricultural Inputs and Chemicals

a) Agricultural inputs (e.g., fertilizers, sludge, manure, compost, soil amendments, mulch) are bought from reputable sources. The type (e.g., cattle) and origin (i.e., produced under proper conditions) of manure is known. Compost is produced under conditions that do not pose a risk of biological, physical or chemical contamination.

b) Application of fertilizers, sludge and soil amendments are applied according to instructions or expert advice. Manure is spread at least 120 days before harvest. Compost is applied at any time.

c) Agricultural chemicals are approved for use and comply with local regulations. They are only bought from licensed suppliers. Containers are not damaged, are properly identified (e.g., name, active ingredient, concentration, PCP\#, manufacturer name and contact info, instructions).

d) Fertilizers, sludge, soil amendments and mulch are stored separate from product and packaging materials, in a covered, clean, dry location, with a label that clearly identifies them. Manure and compost are stored away from water sources and where drifting or leaching is not a risk. Agricultural chemicals are stored in a secure location (e.g., locked cabinet), clean, dry location, with a label that clearly identifies them.

e) Those who apply the agricultural chemicals are properly trained or supervised by someone formally trained and follow recommended instructions.

f) There is a Pest Control Program in place (either by a third-party or self-managed) where bait is not used inside buildings, pest control chemicals are approved for use according to local regulations, pest control devices are labeled and identified in a layout.

4) Section 4-Water Quality

a) Water sources (e.g., private well, surface water, municipal water) are assessed for potential risks (e.g., upstream contamination, animal access, sewage, runoff of agronomic inputs) at least once a year, and preventive or corrective measures have been implemented where needed (e.g., fences, vegetative buffer zones, water tests). NOTE: Follow assessment form

b) Sewage sludge or sewage water is not used on site. Sewage or tertiary water 
is not used for activities where it is in contact with the product (e.g., cleaning, fluming, cooling, drenching). If there is a contamination alert of the water source, it is not used.

c) Tanks, containers or cisterns are cleaned before their first use as storage receptacles of water, and ensures they are in operating conditions (i.e., with lid, no evidence rust or leakage).

d) Water sources are tested for total coliforms and E. coli at least once prior use and once during season from all sources (except municipal water). Strongly suggested for agricultural water (i.e., used for irrigation and preparing solutions of fertilizers and chemicals), and mandatory for water that is in contact with product (i.e., cleaning, fluming, cooling, drenching).

e) Water used for cooling, drenching, fluming or washing product, and misting, cleaning operations comes from a potable source and is either kept potable or the product gets a final rinse with potable water. If water is treated for potability (i.e., with chlorine or any other alternative method), it is done following a validated procedure, $\mathrm{pH}$ and chlorine concentration is monitored.

f) Backflow prevention devices are in place where water is used for agricultural chemical application.

\section{5) Section 5-Harvest and Post Harvest Operations}

a) Before harvest, the production site is inspected to make sure there are no signs of obvious contamination (flooding, wildlife, chemical spills).

b) Product is harvested only after 120 days (minimum) from the time manure was spread, and the pre-harvest interval (PHI) has passed.

c) Product is visually inspected before and during harvest; product does not have obvious signs of contamination, and packaging materials are not source of contamination to the product; fruits and vines that have fallen on the ground are not harvested.

d) Foreign objects and crop debris are removed; damaged product or with obvious signs of contamination is discarded.

e) Product is stored in a clean area, separate from equipment, agronomical chemicals, cleaners, etc.

f) Packaging materials are clean and free of debris, and are not used for any other purposes (carrying tools, chemicals, personal effects, etc.); are kept off the ground and walls $(8 \mathrm{~cm})$; reusable porous materials have an impermeable liner, and non-porous materials are cleaned before used.

6) Section 6-Equipment and Tools

a) Equipment is not used for slaughter operations

b) Equipment and tools that have contact with food are easy to clean, made out of non-porous materials, and are not a potential source of contamination. They are located or installed where there is sufficient space between floors and walls that allows easy cleaning, and stored in a manner that avoids cross-contamination of product or water sources.

c) Equipment is inspected before its use. Equipment (agricultural chemical 
applicator, spreaders, scales, thermometers, $\mathrm{pH}$ meter, chlorinator, etc.) is calibrated according to the manufacturer's instructions at the beginning of the season, when important parts are replaced or when inspection indicates its need.

d) Agricultural chemical application equipment is flushed or rinsed in between applications and in a way that water sources or production site is not contaminated.

e) Cross contamination is avoided by dedicating cloths for wiping product only, and cleaning scales in between use of weighing agricultural chemicals and product.

7) Section 7-Distribution, Transportation and Traceability

a) The cargo area of the vehicle that will transport the product is inspected for cleanliness, is free of pests (or evidence of infestation) and well maintained. The vehicle is constructed in a way that environment elements will not contaminate the load, or that a protective covering (e.g., tarp, plastic wrap) secures the load.

b) Outgoing product is inspected before loading it into the vehicle. When product is loaded, it is placed in a manner that it does not come in contact with other materials that have the potential risk of cross-contamination (e.g., allergens, livestock, and agricultural chemicals).

c) Shipments are recorded (e.g., date, product description and ID, quantity, vehicle inspection, carrier, destination, customer and person responsible).

d) Identification of harvested product is done by using pallet tag, bin tags or other form of identification. Those pallets or bin tags are linked to date of harvest and block or field\#. Outgoing product leaves the premises with an ID\#/Lot\#.

e) It is possible to trace back how and when the outgoing shipment was grown, treated with agricultural chemicals, harvested, processed and stored by referring to records kept.

8) Section 8-Human Welfare, Health and Safety

a) A first aid kit is available and in good condition. Emergency phone numbers (fire brigade, police, hospital) are at hand. Personal protection equipment (e.g., goggles, rubber gloves, rubber boots, masks, aprons) is available, clean and in good condition.

b) Workers are trained in the use of agricultural chemicals (e.g., pesticides), agricultural inputs (e.g., fertilizers, manure) and equipment. Workers are trained in practices related to food safety, personal hygiene and specific to the job. Training is done by a competent/certified person.

c) Training is provided to employees before the season, to new employees, when good practices need to be reinforced. Training is provided in a language that the employee understands.

d) Children do not participate in farming activities. They may help in family farming activities only if such activities do not interfere with school activities and do not attempt against their safety.

e) Workers are aware of transferrable diseases to food (e.g., Hepatitis A, salmonella, E. coli). When showing signs of disease, the person seeks medical at- 
tention as soon as possible, and is removed from activities that may contaminate the product (e.g., handling fresh product). Bandaged wounds are covered with waterproof materials (e.g., rubber gloves).

f) Toilets and hand washing facilities are available, clean, easily accessible and fully equipped (toilet paper, soap, paper towels, hand wipes, hand sanitizer, garbage). There are signs that remind users to wash hands after using the toilet.

\section{9) Section 9-Record Keeping}

a) Person responsible for training demonstrates he/she is competent. Certificates (when needed) are available and up-to-date. Worker's training is recorded and records are available.

b) Health records are kept confidential

c) There is a policy in place where it establishes the controlled areas (as to prevent contamination of the product), visitors are accompanied at all times during the visit of controlled areas, visitors read the policy and sign in a log book before accessing to controlled areas.

d) Cleaning and maintenance materials (detergents, sanitizers, inks, lubricants, food additives, processing aids) are bought from reputable sources. MSDS and letter of no-objection (when required) are kept in file.

e) Toilet and hand washing facilities are cleaned regularly (daily in peak season) and such activities are recorded.

f) There is a list of agricultural chemicals used on site; technical data sheets (TDS) and material safety data sheets (MSDS) are kept on file.

g) The applications of agricultural inputs (e.g., fertilizers, sludge, manure, compost, soil amendments, mulch) and chemicals (e.g., pesticides, herbicides, fungicides) are recorded, including application date, area treated, person responsible, quantity applied, PHI/DAA, etc. Records are available.

h) Water treatment is monitored regularly and recorded.

i) Harvesting information (product, variety, PHI/DAA, harvest date, quantity, block\# or bin tag, type of packaging material used, storage date) is recorded and available.

j) Pest Control Product Numbers (PCP\#), applications and findings are recorded. Corrective actions are taken when there is a trend or pattern that show pest populations increasing.

k) Calibration records of equipment are available. 